\title{
Circulating Myeloid-Derived Suppressor Cell Subsets in Patients with Colorectal Cancer - Exploratory Analysis of Their Biomarker Potential
}

\author{
Subpopulace cirkulujících myeloidních supresových buněk \\ u pacientů s kolorektálním karcinomem - explorativní analýza \\ jejich potenciálu jako biomarkeru
}

Fědorová L. ${ }^{1,2}$, Pilátová K. ${ }^{1,2}$, Selingerová I. ${ }^{1,2}$, Bencsiková B. ${ }^{2,3}$, Budinská E. ${ }^{2}$, Zwinsová B. ${ }^{2}$, Brychtová V. ${ }^{2}$, Langrová M. ${ }^{2}$, Šefr R. 2,4, Valík D. ${ }^{1,2}$, Zdražilová Dubská L. ${ }^{1,2}$

' Department of Laboratory Medicine, Masaryk Memorial Cancer Institute, Brno, Czech Republic

${ }^{2}$ Regional Centre for Applied Molecular Oncology, Masaryk Memorial Cancer Institute, Brno, Czech Republic

${ }^{3}$ Clinic of Comprehensive Cancer Care, Masaryk Memorial Cancer Institute, Brno, Czech Republic

${ }^{4}$ Clinic of Surgical Oncology, Masaryk Memorial Cancer Institute, Brno, Czech Republic

\begin{abstract}
Summary
Background: Myeloid-derived suppressor cells (MDSCs) contribute to tumor escape from host immune surveillance and to tumor progression by producing tumor-promoting factors. We focused on clinical and analytical MDSCs-related issues as potential biomarkers and immune regulators involved in tumor progression. Patients and Methods: We analyzed 10 patients with advanced colorectal carcinoma (CRC) with (M1 subgroup) or without (M0 subgroup) distant metastases at diagnosis. Peripheral blood was collected at diagnosis prior to treatment and subsequently 12 months after therapy initiation. Using multicolor flow cytometry MDSC subsets were evaluated. Monocytic MDSCs (M-MDSCs) were detected as CD45 ${ }^{+} \mathrm{CD} 11 \mathrm{~b}^{+} \mathrm{CD} 33^{+}$ HLA-DR low/- CD14+ CD15-, granulocytic MDSCs (CD33 hi PMN-MDSC) were detected as CD45+

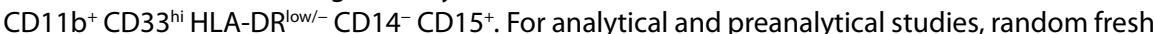
blood specimens predominantly from cancer patients were analyzed. Results: Levels of circulating M-MDSCs were not associated with metastatic disease within advanced CRC patients. Levels of circulating CD33 ${ }^{\text {hi }}$ PMN-MDSCs were elevated in patients with distant metastases compared to T3 M0 subgroup. Circulating M-MDSCs increased upon treatment initiation in 9 out of 10 patients. CD33 $3^{\text {hi }}$ PMN-MDSCs substantially dropped upon treatment initiation in 5 out of 10 patients and substantially increased in 2 out of 10 patients. Analytical part showed that absolute and relative counts within each MDSC subset are correlated. Coefficient of variation (CV) for repeatability was $6-11 \%$ for M-MDSCs and $25-44 \%$ for CD $33^{\text {hi }}$ PMN-MDSCs. CV for reproducibility was higher with $8-22 \%$ for M-MDSCs and $35-79 \%$ for CD33 ${ }^{\text {hi }}$ PMN-MDSCs demonstrating that delay in measurement of MDSCs in whole blood specimen may distort quantification of circulating MDSC subsets. Conclusion: The quantification of MDSC subsets is substantially dependent on the type of specimen examined and its preanalytical processing. Exploratory analysis of M-MDSCs and CD33 ${ }^{\text {hi }}$ PMN-MDSCs in CRC patients revealed different dynamics of M-MDSC and CD33 ${ }^{\text {hi }}$ PMN-MDSC subsets in the context anti-cancer treatment.
\end{abstract}

\section{Key words}

myeloid-derived suppressor cells - preanalytics - colorectal cancer - flow cytometry - immune monitoring
The work was supported by Czech Ministry of Health (projects AZV 16-31966A and DRO 00209805) and Czech Ministry of Education, Youth and Sports (projects LO1413, LM2015089).

Tato práce byla podpořena MZ ČR (projekt AZV 16-31966A a DRO 00209805) a MŠMT ČR (projekt LO1413, LM2015089).

Autoři deklarují, že v souvislosti s předmětem studie nemají žádné komerční zájmy.

The authors declare they have no potential conflicts of interest concerning drugs, products, or services used in the study.

Redakční rada potvrzuje, že rukopis práce splnil ICMJE kritéria pro publikace zasílané do biomedicínských časopisů.

The Editorial Board declares that the manuscript met the ICMJE recommendation for biomedical papers.

$\equiv^{\circ}$

doc. RNDr. Lenka Zdrazilova

Dubska, Ph.D.

Department of Laboratory Medicine Masaryk Memorial Cancer Institute

Zluty kopec 7

Brno 65653

Czech Republic

e-mail: dubska@mou.cz

Prijiato/Accepted: 30. 8. 2017 


\section{Souhrn}

Východiska: Myeloidní supresorové buňky (MDSCs) přispívají k úniku nádoru imunitní kontrole a podporují nádorový růst produkcí růstových faktorů. Zaměřili jsme se na klinické a analytické otázky týkající se MDSCs jako potenciálních biomarkerů a imunitních regulátorů, které se podílejí na progresi nádoru. Soubor pacientů a metody: Analyzovali jsme skupinu 10 pacientů s pokročilým kolorektálním karcinomem (colorectal carcinoma - CRC) a př́tomnými metastázami (podskupina M1), nebo bez metastáz (podskupina M0) v době diagnózy. Krev byla pacientům odebrána v době diagnózy před zahájením protinádorové léčby a dále 12 měsíců po zahájení léčby. Fluorescenční imunoanalýzou na průtokovém

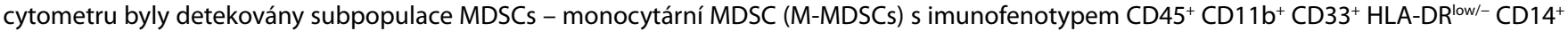

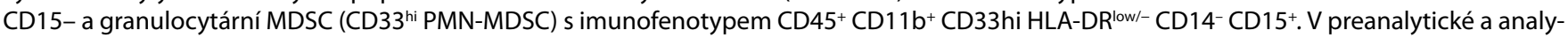
tické části studie byly změřeny náhodně vybrané vzorky krve pacientů s onkologickou diagnózou. Výsledky: Hladina cirkulujících M-MDSCs není asociována s metastatickým CRC. Naopak cirkulující CD33 hi PMN-MDSCs byly zvýšeny u pacientů se vzdálenými metastázami (M1) v porovnání s T3 M0 podskupinou. Cirkulující M-MDSCs byly zvýšeny po podání chemoterapeutické léčby u 9 z 10 pacientů. CD33 ${ }^{\text {hi }}$ PMN-MDSCs značně poklesly po zahájení léčby u 5 z 10 pacientů a byly zvýšeny u 2 z 10 pacientů. Absolutní a relativní počty MDSCs spolu korelovaly a oba mohou být použity pro kvantifikaci MDSCs. Variační koeficient (CV) opakovatelnosti byl 6-11 \% pro M-MDSCs a 25-44 \% pro CD33 hi PMN-MDSCs. CV mezilehlé preciznosti byl vyšší - 8-22 \% u M-MDSCs a 35-79\% u CD33i PMN-MDSCs, což ukazuje, že časová prodleva měření MDSCs ve vzorku plné krve ovlivňuje množství detekovaných MDSCs. Závěr: Kvantifikace subpopulací MDSC je závislá na typu zkoumaného vzorku a jeho preanalytickém zpracování. Explorativní analýza M-MDSCs a CD33 hi PMN-MDSCs u pacientů s CRC ukázala, že dynamika cirkulujících MDSCs před a po podání protinádorové léčby je odlišná s ohledem na konkrétní subset myeloidních supresorových buněk.

Klíčová slova

myeloidní supresorové buňky - preanalytika - kolorektální karcinom - průtoková cytometrie - imunomonitoring

\section{Introduction}

Cancer development is caused by accumulation of intrinsic cellular changes that are shaped by host-related factors such as inflammatory cells and cytokine/chemokine levels in the tumor macro and microenvironment. Chronic inflammation supports cancer angiogenesis, glycolytic phenotype and Th2 immune response and thus contributes to cancer progression [1,2].

Myeloid-derived suppressor cells (MDSCs) are regulatory myeloid cells with capability to inhibit T-cell effector functions. MDSCs can elicit their immunosuppressive functions by various mechanisms relying on production of 1. immunoregulatory enzymes, such as arginase-1, indoleamine 2,3 dioxygenase and nitric oxide synthase $2 ; 2$. reactive oxygen species and 3 . suppressive cytokines, such as TGF $\beta$, IL-10 and IL-8. The latter is associated with tolerogenic action of MDSCs leading to T-cell tolerogenic phenotype or Treg cell expansion.

In recent years, MDSCs were studied in the context of tumor growth where they contribute to tumor escape from the host immune surveillance [3] and in the context of their targeting by anticancer therapeutics. Association between increased circulating MDSC number and worse prognosis has been reported across various cancer types (summarized and reviewed in [4]).
In humans, MDSC are characterized as $\mathrm{CD}_{3}{ }^{+}$cells, common myeloid marker, and $C D 11 b^{+}$with no marker for mature lymphoid or myeloid on their membrane including HLA-DR. Further, MDSCs can be divided into two main groups based on expression CD14 and CD15 as CD14+ CD15- monocytic MDSCs (M-MDSCs) and CD14- CD15+ granulocytic MDSCs (PMNMDSCs) [5]. Published data show great variability in immunophenotype of cells evaluated as "MDSCs" in cancer-related studies in humans [4]. Majority of published studies focuses on M-MDSCs or total MDSCs. Granulocytic fraction of MDSCs can be defined as low density immature myeloid PMN-MDSCs or CD33 ${ }^{\text {hi }}$ mature presumably activated PMN-MDSCs [1].

We have previously shown increased numbers of circulating M-MDSC in colorectal cancer (CRC) patients compared to control population [6]. In recent work, we focused on MDSC subsets in the clinically relevant context pharmacologically administered G-CSFs [1].

Here, we addressed analytically and clinically relevant issues relating to circulating MDSC subsets as potential cancer biomarkers and immune regulators in cancer patients.

\section{Material and methods}

Patients

The CRC group was pilot part of the Colobiome project approved by the
Ethics Board of Masaryk Memorial Cancer Institute (MMCI), Brno, Czech Republic, and all patients signed informed consent for the study. Patients were enrolled to the study at the time of diagnosis of advanced CRC with (M1 subgroup) or without (M0 subgroup) distant metastases at diagnosis. The analysis of circulating MDSC subsets was performed at diagnosis prior treatment and subsequently 12 months after therapy initiation. For analytical and preanalytical studies, random fresh blood specimens predominantly from cancer patients were analyzed.

\section{Circulating MDSC subset detection}

Peripheral blood specimens were collected in a $2.6 \mathrm{ml} \mathrm{S-Monovette}{ }^{\circ}$ tube with tripotassium ethylenediaminetetraacetic acid (K3EDTA) anticoagulant in a phlebotomy room in close proximity to the laboratory where the analysis was performed. The blood specimens were mixed for several minutes on the roller mixer. Immediately after that, complete blood count and differential was obtained on Sysmex XE-5000 haematology analyzer. Total white blood cell count was used for calculation of the absolute count of MDSC subsets. MDSC subsets were evaluated within 3 hours after blood withdrawal by Navios flow cytometer and software (Beckman Coulter) by multicolour protocol using 
fluorescence-labelled antibodies CD33FITC, CD14-PE, HLA-DR-PC5, CD11bAPC, CD45-PacBlue, CD15-KrO from Beckman Coulter. M-MDSCs were detected as $\mathrm{CD}_{4} 5^{+} \mathrm{CD} 11 \mathrm{~b}^{+} \mathrm{CD} 33^{+} \mathrm{HLA}$ $\mathrm{DR}^{\text {low/- }} \mathrm{CD} 14^{+} \mathrm{CD} 15^{-}$and $\mathrm{CD} 33^{\text {hi }} \mathrm{PMN}-$ MDSC subset was detected as CD45+ CD11 b ${ }^{+} \mathrm{CD}_{3} 3^{+} \mathrm{HLA}^{-D R^{\text {low/- }}}$ CD14- CD15 ${ }^{+}$. The number of MDSCs was expressed as percentage from total circulating white blood cells and as an absolute MDSC count calculated from total white blood cell count.

\section{Statistical analysis}

Wilcoxon test was used to compare medians in two groups. Absolute MDSC counts at diagnosis and after treatment were compared by paired variant of Wilcoxon test. All statistical tests were performed by the $\mathrm{R}$ software version 3.5.1. $p$-values $<0.05$ were considered to be statistically significant.

\section{Results and discussion}

Circulating MDSC subsets - analytical and preanalytical aspects

Using multicolor immunophenotyping protocol, we enumerated M-MDSCs and CD33 ${ }^{\text {hi }}$ PMN-MDSCs in fresh peripheral blood specimens. The majority of studies on MDSC in humans are performed using peripheral blood. The number of MDSCs can be reported as absolute cell count per volume of blood or as relative count such as percentage of cell in total white blood cells (WBC) and the latter approach to quantification of circulating MDSC numbers prevails. Here we show that in both MDSC subsets absolute and relative counts are correlated (Fig. 1a) and therefore equal information may be derived from either method of MDSC enumeration.

Quantification of circulating MDSCs may be influenced by several preanalytical and analytical factors. First, for practical reasons, MDSCs are often investigated in cryopreserved separated peripheral blood mononuclear cell (PBMC) specimens. Gradient centrifugation used for PBMC isolation can be expected to deplete PMN-MDSCs together with granulocytes. Moreover, cryopreservation of PBMC samples decreases MDSCs and mainly their a
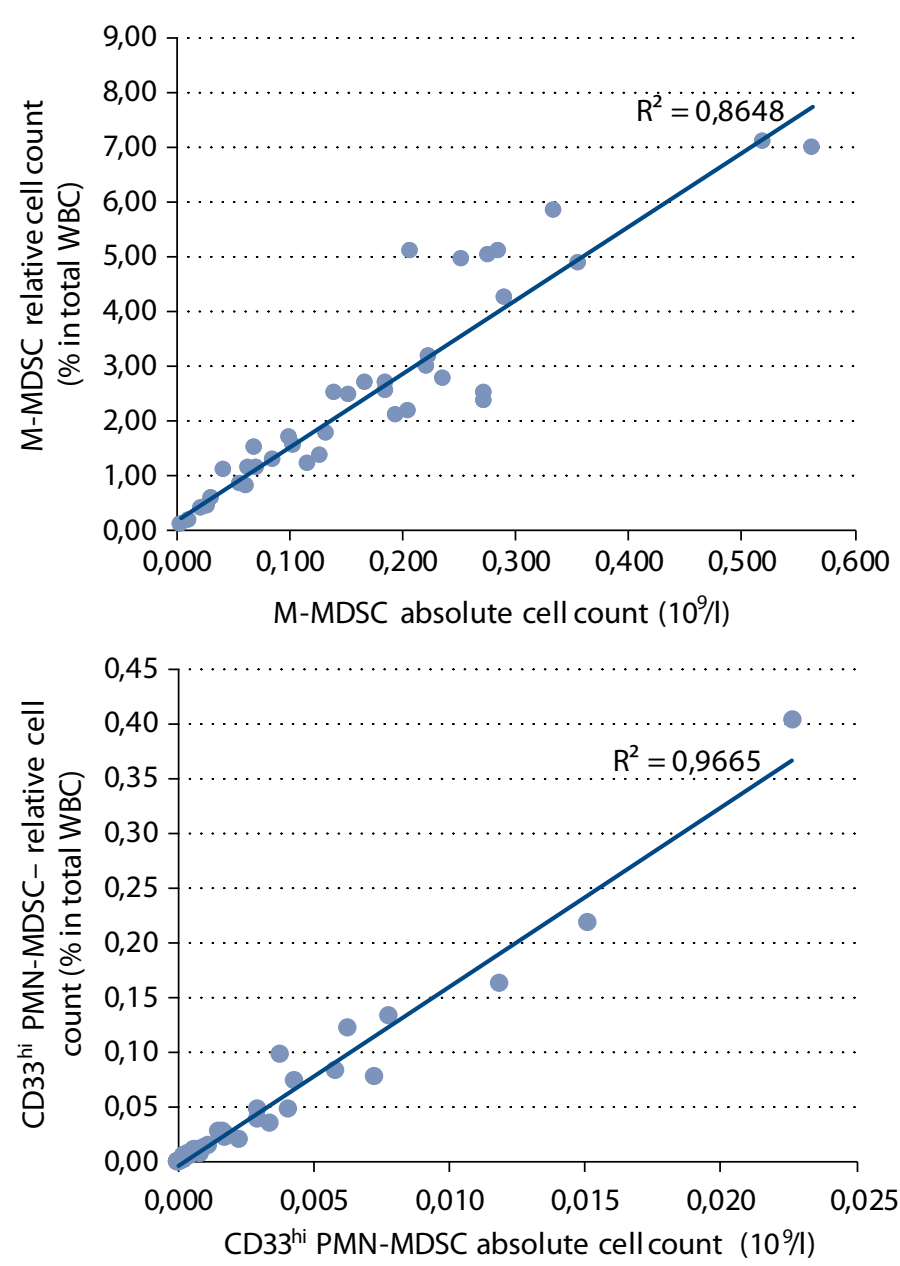

b

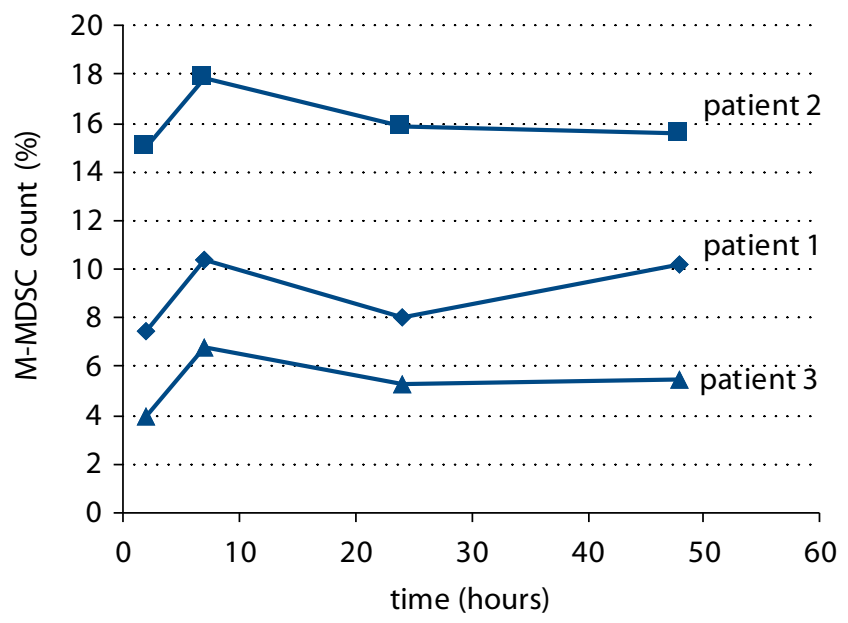

Fig. 1. a) Comparison of relative and absolute MDSC enumeration in peripheral blood. MDSCs were evaluated in 38 samples of peripheral blood withdrawn to K3EDTA from control group and patients with CRC at the time of diagnosis. b) Time-to-analysis related changes of M-MDSC relative count. Measurement of M-MDSCs was performed in three whole blood specimens of CRC patients in 2, 7, 24 and 48 hours from blood collection into K3EDTA.

MDSCs - myeloid-derived suppressor cells, K3EDTA - tripotassium ethylenediaminetetraacetic acid, M-MDSC - monocytic MDSCs, CRC - colorectal cancer, WBC - white blood cell 


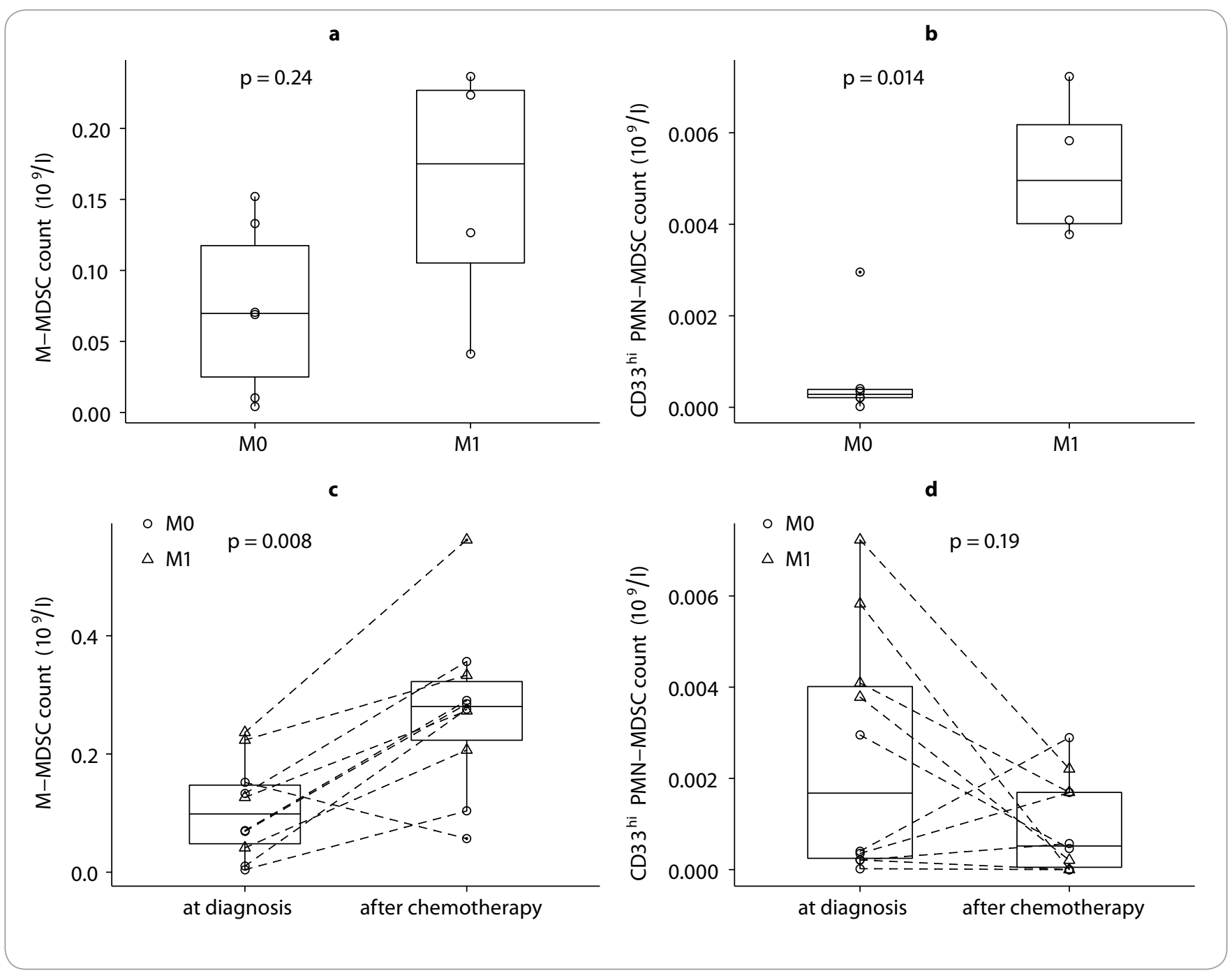

Fig. 2. a) Difference in baseline M-MDSC counts in patients with primary metastatic CRC (M1) and patients without detected metastases (M0) at diagnosis. b) Difference in baseline circulating CD33 ${ }^{\text {hi }}$ PMN-MDSC counts in colorectal patients with metastatic disease (M1) and advanced CRC without distant metastases (M0) at diagnosis.C) Comparison of absolute circulating M-MDSC count at diagnosis and after chemotherapy initiation in advanced CRC patients. d) Comparison of absolute circulating CD33 $3^{\text {hi }}$ PMN-MDSC count at diagnosis and after chemotherapy initiation in advanced CRC patients.

M-MDSC - monocytic myeloid-derived suppressor cells, CRC - colorectal cancer, CD $33^{\text {hi }}$ PMN-MDSC - granulocytic MDSCs

granulocytic subset due to their fragile nature $[7,8]$. Second, time between blood collection and the measurement probably also influences frequency of circulating MDSCs. However, published data are not consistent in this respect $[8,9]$. Time-to-analysis related changes in M-MDSC frequency may be caused by adhesion of the monocytic cells to the vial surface or by phenotype changes [8]. Granulocytic cells on the other hand loose viability in the stored blood specimens. We tested analytical variability (measurement precision) of MDSC quantification in
K3EDTA whole blood specimens of CRC patients to assess 1 ) reproducibility in time and 2) repeatability immediately after blood collection. Repeatability was performed on four independent measurements within 2 hours from blood collection. Reproducibility was performed in subsequent time points $-2,7,24$ and 48 hours from the blood collection while storing blood specimen at $2-8{ }^{\circ} \mathrm{C}$. Coefficient of variation (CV) for repeatability was $6-11 \%$ for M-MDSCs and $25-44 \%$ for CD33 ${ }^{\text {hi }}$ PMN-MDSCs. CV for reproducibility was higher with $8-22 \%$ for M-MDSCs and $35-79 \%$ for
CD33hi PMN-MDSCs demonstrating that delay in measurement of MDSCs in whole blood specimen may distort quantification of circulating MDSC subsets. M-MDSCs are defined and detected as HLA-DR-/low+ cells and expression of this marker is vulnerable to the down and up-regulation on cell surface upon blood collection into anticoagulants [10]. We observed transient increase of M-MDSC in K3EDTAanticoagulated whole blood specimen in the time point 7 hours from the blood collection that dropped at day 2 and 3 (Fig. 1b). As M-MDSC enumeration is 
critically dependent on the expression of HLA-DR molecule on monocytes, the recommendations for preanalytical handling of specimen for HLA-DR/mono analysis should be followed when M-MDSCs are quantified. To detect the level of HLA-DR on monocytes to evaluate the level of immunosuppression in sepsis, it is recommended to perform the cell staining within 2 hours after sampling [11]. Taken together, inconsistency in quantification of CD33 ${ }^{\text {hi }}$ PMN-MDSCs related to delay from blood collection to analysis is likely to be attributed to fragility of granulocytic cells and to some extent also by unspecific binding of antibodies to decayed non-viable cells. The main cause in variation in M-MDSC count within time to analysis of whole blood is caused by ex vivo changes in HLA-DR surface expression. We conclude that a laboratory providing quantification of circulating MDSC subsets in peripheral blood should develop robust and consistent approach to preanalytics not only in term of the type of anticoagulants used for blood collection but also in terms of storage conditions and exact time from the blood collection to analysis.

\section{Circulating MDSC subsets \\ in CRC patients}

In our exploratory analysis of 10 patients with advanced CRC treated with standard adjuvant or palliative treatment predominantly with fluoropyrimidines, we observed different therapy-related dynamics in MDSC subsets. Levels of circulating M-MDSCs were not associated with metastatic disease within advanced CRC patients (Fig. 2a). Levels of circulating CD33 ${ }^{\text {hi }}$ PMNMDSCs were elevated in patients with distant metastases compared to T3 M0 subgroup (Fig. 2b). Circulating M-MDSCs increased upon treatment initiation in 9 out of 10 patients (Fig. 2c). CD33 ${ }^{\text {hi }}$ PMN-MDSCs substantially dropped upon treatment initiation in 5 out of 10 patients and substantially increased in 2 out of 10 patients (Fig. 2d). Therefore, circulating MDSC subsets, namely M-MDSC and CD33 $3^{\text {hi }}$ PMN-MDSCs, revealed unbalanced relation to the disease extent and different timedependence in the context of anti-cancer therapy, which pointed out that circulating M-MDSCs and CD $33^{\text {hi }}$ PMNMDSCs should not be evaluated as a pooled cell type in clinical cancer research.

It is not yet clear whether elevation of a particular circulating MDSC subsets reflects rather the presence and extent of malignant disease or functional cancerpromoting properties of the tumor, including level of immune suppression and vascular endothelial growth factor stimulation, or the host response to the disease, such as acute-phase marker. Exploring a correlation of circulating MDSC subsets and routinely exploited acute phase marker, $\mathrm{C}$-reactive protein (CRP), we observed that unlike WBC count, number of circulating M-MDSCs or CD33 ${ }^{\text {hi }}$ PMN-MDSCs was not associated with plasma CRP elevation in CRC patients at the diagnosis (data not shown).

\section{Conclusions}

In recent years, scientific interest in the role of immunosuppressive MDSCs in cancer has moved to clinical research and is approaching the clinical practice. Detection of human MDSCs requires multicolor flow cytometry to distinguish MDSC subsets. Beyond the issue of immunophenotypic MDSC definition, the quantification of both M-MDSC and CD33 ${ }^{\text {hi }}$ PMN-MDSCs is substantially dependent on the type of specimen examined (full blood vs. isolated and frozen PBMCs) and its preanalytical processing in terms of the delay between blood withdrawal and MDSC enumeration. Analysis of MDSC subsets in CRC patients revealed different dynamics of M-MDSCs and CD33 ${ }^{\text {hi }}$ PMN-MDSCs in the context anticancer treatment and therefore the biomarker potential of MDSC should be explored with respect to distinct MDSC subsets.

\section{References}

1. Pilatova K, Bencsikova B, Demlova R et al. Myeloid-derived suppressor cells (MDSCs) in patients with solid tumors: considerations for granulocyte colony-stimulating factor treatment. Cancer Immunol Immunother. In press 2018. doi: 10.1007/s00262-018-2166-4.

2. Greplova K, Selingerova I, Valik D et al. Lactate Dehydrogenase - old tumour marker in the light of current knowledge and preanalytic conditions. Klin Onkol 2017; 30 (Suppl 1): 156-158.

3. Talmadge JE, Gabrilovich DI. History of myeloid-derived suppressor cells. Nat Rev Cancer 2013; 13(10): 739-752. doi: 10.1038/nrc3581.

4. Shipp C, Speigl L, Janssen $\mathrm{N}$ et al. A clinical and biological perspective of human myeloid-derived suppressor cells in cancer. Cell Mol Life Sci 2016; 73(21): $4043-$ 4615. doi: 10.1007/s00018-016-2278-y.

5. Peranzoni E, Zilio S, Marigo I et al. Myeloid-derived suppressor cell heterogeneity and subset definition. Curr Opin Immunol 2010; 22(2): 238-244. doi: 10.1016/j. coi.2010.01.021

6. Pilatova K, Budinska E, Benscikova B et al. Circulating myeloid suppressor cells and their role in tumour immunology. Klin Onkol 2017; 30 (Suppl1): 166-169.

7. Kotsakis A, Harasymczuk M, Schilling B et al. Myeloidderived suppressor cell measurements in fresh and cryopreserved blood samples. J Immunol Methods 2012; 381(1-2): 14-22. doi: 10.1016/j.jim.2012.04.004.

8. Grutzner E, Stirner R, Arenz L et al. Kinetics of human myeloid-derived suppressor cells after blood draw. J Transl Med 2016; 14: 2. doi: 10.1186/s12967-015-0 755-y

9. Florcken A, Takvorian A, Singh A et al. Myeloid-derived suppressor cells in human peripheral blood: Optimized quantification in healthy donors and patients with metastatic renal cell carcinoma. Immunol Lett 2015; 168(2): 260-267. doi: 10.1016/j.imlet.2015.10.001.

10. Docke WD, Hoflich C, Davis KA et al. Monitoring temporary immunodepression by flow cytometric measurement of monocytic HLA-DR expression: a multicenter standardized study. Clin Chem 2005; 51(12): 2341-2347. doi: 10.1373/clinchem.2005.052639.

11. Monneret G, Venet F. Monocyte HLA-DR in sepsis: shall we stop following the flow? Crit Care 2014; 18(1): 102. doi: 10.1186/cc13179. 